\title{
THE IMPACT OF SERVICE QUALITY AND PUBLIC RELATIONS ON PATIENT SATISFACTION IN HOSPITALS
}

\author{
HASTANELERDE HIZMET KALITTESİ VE HALKLA İLISSKILERINN HASTA \\ MEMNUNIYETINE ETKISII
}

\author{
Birol BÜYÜKDOĞAN ${ }^{1}$ \\ Hasan GEDİK ${ }^{2}$ \\ Yüksel DEREL $\dot{I}^{3}$ \\ Ömer TANYELI ${ }^{4}$
}

\begin{abstract}
Service quality and customer satisfaction is a subject of public relation and marketing communication. This research was made in order to evaluate the level of satisfaction of patients who receive treatment at Cardiovascular Surgery Service of Konya Meram Medical Faculty Hospital, regarding the services provided in the hospital, and increase quality of the services provided. As a cross-sectional research, it was made with questionnaire technique between April 2014 and October 2015, including 298 patients who received inpatient treatment and were discharged from the hospital. 51\% of the participants in the research were men and the $49 \%$ of them were women. Satisfaction rates were ensued as $82 \%$ in polyclinic services, $74 \%$ in clinic services, $77 \%$ in other healthcare services and bureaucratic procedures, $80 \%$ in personnel services, and $82 \%$ in rights of patients, $68 \%$ in physical condition and $66 \%$ in cafeteria services. $73 \%$ of the patients indicated that they would recommend to familiars who would like to receive health care service. Based on the research, a great majority of the patients who receive inpatient treatment are satisfied with the hospital services.
\end{abstract}

Keywords: Marketing Communication, Public Relations, Patient Satisfaction, Service Marketing, Service Quality,

$\ddot{\mathbf{O z}}$

Müşteri memnuniyeti hizmet kalitesi, halkla ilişkiler ve pazarlama iletişimi konularından bir tanesidir. Bu çalışma, Konya Meram Tıp Fakültesi Hastanesi Kalp ve Damar Cerrahisi Servisinde tedavi gören hastaların, hastane tarafından verilen hizmetlerle ilgili memnuniyet düzeylerini ölçmek ve hizmet kalitesini artırmak amacıyla yapılmıştır. Kesitsel tipteki bu araştırma, yatarak tedavi gören ve taburcu edilen 298 hastada, Nisan 2014-Ekim 2015 tarihleri arasında anket tekniği kullanılarak yapılmıştır. Araştırmaya katılanların \% 51'i erkek, $\%$ 49’u ise kadındır. Memnuniyet oranları poliklinik hizmetlerinde \% 82, klinik hizmetlerinde \% 74, diğer sağlık ve bürokratik işlemlerde $\% 77$, personel hizmetlerinde $\% 80$, hasta haklarında $\% 82$, fiziksel durumda $\% 68$, kafeterya hizmetlerinde \% 66 olarak ortaya çıkmıştır. Hastaların \% 73’ü hastaneyi sağlı hizmeti almak isteyen tanıdıklarına önereceklerini belirtmişlerdir. Çalışmada, yatarak tedavi gören hastaların büyük çoğunluğu hastane hizmetlerinden memnundur.

Anahtar Kelimeler: Pazarlama İletişimi, Halkla İlişskiler, Hasta Memnuniyeti, Hizmet Pazarlaması, Hizmet Kalitesi,

\footnotetext{
${ }^{1}$ KTO Karatay Üniversitesi, SBBF, Sosyal Hizmet Bölümü, birol.buyukdogan@karatay.edu.tr

${ }^{2}$ KTO Karatay Üniversitesi, iYBF, Sigortacılık ve Sosyal GÜvenlik Bölümü, hasan.gedik@karatay.edu.tr

${ }^{3}$ Necmettin Erbakan Üniversitesi, Meram Tıp Fakültesi, Kalp ve Damar Cerrahisi ABD, ydereli@konya.edu.tr

${ }^{4}$ Necmettin Erbakan Üniversitesi, Meram Tıp Fakültesi, Kalp ve Damar Cerrahisi ABD, otanyeli@konya.edu.tr
} 


\section{Introduction}

Regardless if manufacturing industries or the service industry public relations is an organization that undertakes the operations like getting recognition, approval, satisfaction and recommendation of businesses by the target market. In order to reach a better level on this matter, customers saticfaction, ensuring customer needs and evaluating institution's service quality are required. (Hatem, 2015; Kavuncubaş1, 2000, s. 292-293). This is also a matter of perception, as well. The perception which institution's goods and services create upon customers, is significant for maintaining the institution. For this purpose, checking up on customers constantly is needed. Checking up on customers is also substantial for corporate reputation which is the perception received by them.

Corporate reputation consists of three fundamental features, they are as follows (Geçikli, 2013, s. 137):

- Feature of thoughts about institution in a society,

- Context and dispersion of these thoughts,

- Evaluation of institution and relevance features.

Especially, continuity of corporate reputation in the service industry comes true with maintaining bilateral and symmetrical public relations process associated with target market, without a hitch. Hospitals which everyone utilize somehow, are one of the leading institutions. Satisfaction of patients, the most important input for the hospitals, matters in terms of both public relations and sustainability of service quality. Patient satisfaction is a notion related to at what rate patient's needs and expectations are fulfilled. Patient's needs and expectations may differ depending on numerous variables such as gender of the patient, age, condition of disease, educational status, education level and social security.

Due to the competition between them, receiving feedback, from consumers, about their own products and services is essential for the hospitals in order to maintain their corporate reputation. Additionally, questionnaires for patient satisfaction provide with important information for both executive policy and development of service quality. With iterative surveys, hospitals will contribute to the policies and programmes which are suitable for the patients whose needing change by time (Draper, Cohen, \& Buchan, 2001). Although the perception and the measurement of patient satisfaction seem considerably ignored in health sector in the developing countries (Jenginson, Coulter, Bruster, Richards, \& Chandola, 2002), it is seen that, most of the studies which were performed in recent years about patient satisfaction in hospitals have the approach within the frame of perception of patient satisfaction and corrective actions were evaluated with the patient's point of view (Bogale, Kassa, \& Ali, 2015; Deitrick, Bokovoy, Stern, \& Panik, 2006; Draper, Cohen, \& Buchan, 2001).

Demographical variables in the measurement of patient satisfaction can be broadly headlined as gender, age, marital status, educational status, employment status, income, social security, residence, duration of hospital stay and hospitalization frequency. Doctor and nursing care, medical care, visits, cleanliness, patient information, first application and discharge of patient, comfort of the patient rooms and the material condition of the hospital may be headlined as dimensions of patient satisfaction (Hekkert, Cihangir, Kleefstra, \& Berg, 2009; Bogale, Kassa, \& Ali, 2015; Quintana, et al., 2006; Ercan, Idız, \& Kan, 2004).

\section{Literature Analysis}

Many studies have been carried out in the field of patient satisfaction in both Turkey and other countries. Hekkert et al. (2009) have measured the patient satisfaction in different 
dimensions. Dimensions of patient satisfaction have been ensued relatively high such as (avg. = 3.96) for "reception period", (avg. = 3.95) for "nursing care", (avg. = 3.99) for "medical care" and (avg. = 3.81) for "patient autonomy". Dimensions of patient satisfaction have been resulted in midlevel values such as (avg. $=3.65)$ for "informing", $($ avg. $=3,54)$ for both "discharge" and "post treatment care".

Bogale et al. (2015) have measured the patient satisfaction in different dimensions. According to this, the satisfaction rates were resulted as $84 \%$ for "punctuality of workers during working hours", $80 \%$ "ease of service access", $80 \%$ for "respectability of healthcare professionals" and 79\% for "encouragement for acquisition of knowledge". The highest mean value was found as 4.47 and $93 \%$ of satisfaction percentage for "wording of employee in communication" and the lowest mean value was found as 3.88 and $77 \%$ of satisfaction percentage for "waiting time for laboratory service".

Jenginson et al. (2002) have researched the patient satisfaction under different titles. Such as, "information and education", "care coordination", "physical comfort", "emotional support", "respect for patient's choice" and "continuity of care". In another study, Draper et al. (2001) have measured the patient satisfaction in six key subjects. These are, "access", "general patient information", "information related to treatment", "complaint management", "physical environment" and "period of discharge".

Çelikalp and colleagues (2011) have measured the patient satisfaction by using the Scale for Measurement of Service Satisfaction in the studies they have carried out. Accordingly, the dimensions of patient satisfaction have been resulted as $52.12 \%$ for polyclinic services, $54.65 \%$ for clinical services, $55.47 \%$ for other healthcare services and bureaucratic procedures, $63.56 \%$ for employee services, $54.85 \%$ for patient rights, $53.62 \%$ for physical condition, $47.87 \%$ for cafeteria services and $59.81 \%$ for general assessment.

Çınaroğlu and Şahin (2012) have performed a study about corporate reputation and public opinion of the hospitals in Ankara. According to the results of the study, it is confirmed that the patients' perception of corporate reputation and public opinion has a positive and strong relation with employee satisfaction indicator, and inpatient satisfaction has a positive and strong relation with the number of complaints of patient. Satisfaction of healthcare services in Turkey in 2015 is 72,3\% (TUIK, 2015). Employment and patient oriented satisfaction of employee who provides service, along with the harmony with the teammates is important for patient satisfaction. Thus, increasing job satisfaction will bring along the efficiency (Uz, 1997, s. 129).

This study has been carried out in order to increase the service quality and measure the satisfaction, based on services provided by the hospital, level of the patients who gets treatment at Cardiovascular Surgery Service of Konya Meram Medical Faculty Hospital. Bilateral and symmetrical communication, one of the public relations model of the related hospital, will come true and how the patients perceive the provided service will be revealed by the information which will be obtained from this study. Thanks to this information, customer policies of the hospital and the service quality will be ensured to increase. The study will deeply execute the satisfaction measurements which have been performed in the strict sense in the medical faculty hospital and will contribute to fill a gap in the field of these kind of studies by being the first study about the patients who have undergone through a treatment process and seriously vital operations from cardiovascular surgery. In addition to this, this study is evaluated as to contribute to the studies on developing regulations about patient rights. 


\section{Design and Method}

This research, measuring the patient satisfaction and deducing in terms of public relations, is an applied research which is based on empirical approach and has used the technique of collecting data via questionnaire. The research is designed as cross sectional research out of descriptive search types.

The question of the research is how the patients perceive the dimensions of hospital services in terms of service quality. For this purpose, following hypotheses will be tested:

H1: General patient satisfaction differs significantly with regard to the gender.

$\mathrm{H} 2$ : General patient satisfaction differs significantly with regard to the marital status.

H3: General patient satisfaction differs significantly with regard to the age.

H4: General patient satisfaction differs significantly with regard to the educational status.

H5: General patient satisfaction differs significantly with regard to the occupation.

H6: General patient satisfaction differs significantly with regard to the monthly income level.

H7: General patient satisfaction differs significantly with regard to the social security. frequency.

H8: General patient satisfaction differs significantly with regard to the hospitalization

H9: General patient satisfaction differs significantly with regard to the hospital room type.

H10: There is a significant relation between the patients" "satisfaction level" and "recommending the hospital to familiars".

The universe of the research is all the patients who gets inpatient treatment at Cardiovascular Surgery Service of Konya Meram Medical Faculty Hospital and gets discharged. The research was made by using the questionnaire technique on all the patients who have got inpatient treatment at the cardiovascular surgery service of the hospital between April 2014 and October 2015. Data collecting tool, Scale for Measurement for Service Satisfaction, was developed by Ercan and colleagues (2004). Data collecting tool was firstly applied as pilot scheme on 30 patients, after the period of validity, reliability, and factor analysis, it was applied on 350 patients. 52 questionnaire forms were not found adequate for the research and 298 forms were found adequate and included in the research.

Questionnaire form consists of 53 questions and two chapters. First chapter comprises of the questions showing the demographical state of the patients such as gender, marital status, age, educational status, occupation, monthly income, hospitalization frequency and social security of the patients. Second chapter is a Likert type (Likert 5) scale and comprises of eight sub scales and 43 questions. Sub scales consist of dimensions of the evaluations of polyclinic services, clinical services, other healthcare services and bureaucratic procedures, employees, patient rights, physical condition of the hospital, cafeteria services and the general assessment (recommending the hospital). 43 items in the scale were scored between $0-4$. The lowest score which can be obtained from the scale is 0 while the highest one is 172 . Reliability coefficient of the research (cronbach's alpha) was found as 0.683 .

Questionnaire form has been filled in by the doctors who had career education on cardiovascular surgery doing face to face meetings with the patients who got inpatient treatment and discharged. At the beginning of the research, an approval has been received 
from Necmettin Erbakan University Meram Medical Faculty Noninvasive Clinical Researches Ethics Committee on 4th of April 2014, and ethical principles were followed during the research. The aim of the study was explained to the patients and their permissions for the study were received before applying the questionnaires. There is not any kind of information that would reveal the identity of the patients.

SPSS-22 software package was used to analyze the obtained data. In order to evaluate the data, measurement of percentage, frequency, arithmetic mean, and standard deviation out of definitive statistical methods were used along with Mann-Whitney $U$ test for comparison, and Sperman rank correlation coefficient analyses were made for the relation analyses.

\section{Findings and Discussion}

Research was made on 298 patients. Rate of men and women are close to eachother. $49.7 \%$ of the paritcipants are women, $50.3 \%$ of them are men. $88.6 \%$ of the participants are married, $48.3 \%$ of them are over the age of $61.47 .7 \%$ of the participants are graduated from primary school while $30.9 \%$ of them are housewives, $47 \%$ of them live in the cities and $81.5 \%$ of them have got their first inpatient treatment at cardiovascular surgery (Table 1).

Table 1: Demographic Values $(\mathbf{n}=298)$

\begin{tabular}{|c|c|c|c|c|c|}
\hline & $\mathbf{n}$ & $\%$ & & $\mathbf{n}$ & $\%$ \\
\hline Gender & & & Occupation & & \\
\hline Woman & 148 & 49.7 & Housewife & 92 & 31 \\
\hline Marital status & & & Worker & 68 & 23 \\
\hline Married & 264 & 89 & Civil servant & 33 & 11 \\
\hline $0-15$ & 11 & 3.7 & Once & 243 & 82 \\
\hline $16-30$ & 10 & 3.4 & Twice & 48 & 16 \\
\hline $31-45$ & 22 & 7.4 & Three or more & 7 & 2.3 \\
\hline $46-60$ & 111 & 37 & & & \\
\hline High schools and equivalents & 62 & 21 & & & \\
\hline University & 33 & 11 & & & \\
\hline Graduate & 1 & 0.3 & & & \\
\hline
\end{tabular}

In this research, gender, marital status, age, educational status, occupation, monthly income, social security, residence, hospitalization frequency, hospital room condition and recommending the hospital to familiars have been received for consideration as the variables that may affect the patient satisfaction. Patient satisfaction was investigated in a single piece as a whole with the general scale score, and as a parts of a whole with eight sub scales. Sub scales consists of the dimensions of evaluations of polyclinic services, clinical services, other healthcare services and bureaucratic procedures, employees, patient rights, physical condition of the hospital and cafeteria services, and the general assessment of recommending the hospital.

\section{Scores}

\subsection{Difference Levels Between Demographical Variables and Satisfaction}

Mean values of the data (p:0.067) resulted normal in the normality test which has been performed in order to define which test would be applied for the analyses. The mean values of other sections have not ranged within normal distribution. 
Due to the fact that the Homogeneity test which has been performed afterwards resulted in homogenously mean values (p:0.320) with an exception of gender state, Parametric analyses have been carried out, and Non-parametric analyses were applied in the analyses which has been performed with the other satisfaction values.

Table 2: Difference Levels Related to Demographical Variables and Satisfaction Scores

\begin{tabular}{|c|c|c|c|c|c|c|c|c|c|c|c|c|}
\hline Sub scales & Mean & $\mathrm{SS}$ & 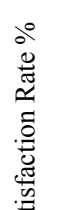 & $\frac{\dot{0}}{\tilde{D}}$ & 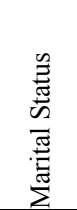 & $\underset{4}{80}$ & 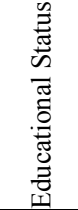 & 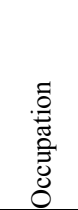 & 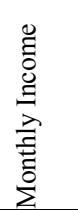 & 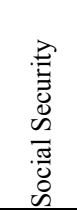 & 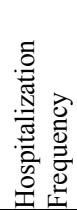 & 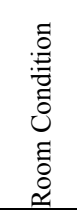 \\
\hline & & & & $\mathrm{P}$ & $\mathrm{P}$ & $\mathrm{P}$ & $\mathrm{P}$ & $\mathrm{P}$ & $\mathrm{P}$ & $\mathrm{P}$ & $\mathrm{P}$ & $\mathrm{P}$ \\
\hline Polyclinic services & 3.20 & 0.39 & 79.91 & 0.047 & 0.810 & 0.527 & 0.869 & 0.258 & 0.090 & 0.2 & 0.015 & 0.001 \\
\hline Clinical services & 2.98 & 0.43 & 74.31 & 0.249 & 0.543 & 0.078 & 0.680 & 0.063 & 0.000 & 0.21 & 0.065 & 0.165 \\
\hline $\begin{array}{l}\text { Other healthcare services and } \\
\text { bureaucratic procedures }\end{array}$ & 2.90 & 0.42 & 72.07 & 0.707 & 0.266 & 0.000 & 0.000 & 0.130 & 0.029 & 0.43 & 0.044 & 0.077 \\
\hline Employee services & 3.19 & 0.64 & 80.00 & 0.299 & 0.046 & 0.942 & 0.39 & 0.141 & 0.059 & 0.58 & 0.181 & 0.618 \\
\hline Patient rights & 3.27 & 0.28 & 81.60 & 0.142 & 0.601 & 0.204 & 0.44 & 0.175 & 0.801 & 0.42 & 0.833 & 0.759 \\
\hline Physical condition & 2.71 & 0.56 & 68.06 & 0.210 & 0.029 & 0.118 & 0.220 & 0.052 & 0.088 & 0.03 & 0.042 & 0.518 \\
\hline Cafeteria services & 2.65 & 1.13 & 66.00 & 0.576 & 0.182 & 0.033 & 0.145 & 0.497 & 0.146 & 0.42 & 0.078 & 0.325 \\
\hline Recommending the hospital & 2.90 & 1.42 & 72.25 & 0.076 & 0.238 & 0.029 & 0.811 & 0.688 & 0.698 & 0.04 & 0.273 & 0.274 \\
\hline General average & 2.98 & 0.30 & 74.90 & 0.745 & 0.396 & 0.079 & 0.739 & 0.502 & 0.189 & 0.114 & 0.219 & 0.039 \\
\hline
\end{tabular}

It has been found that the hospital services related general satisfaction rate of patients according to the SMSS is $74.9 \%$ and it is evaluated to be at a good level. Considering the sub scale scores, the satisfaction rates are $81.60 \%$ for annunciation of patient rights, $80 \%$ for employee services, $79.91 \%$ for polyclinic services, $74.31 \%$ for clinical services, $72.25 \%$ for recommending the hospital, $72.07 \%$ for other healthcare services and bureaucratic procedures, $68.06 \%$ for physical condition and $66 \%$ for cafeteria services (Table 2).

As a result of t test which is performed related to the general average, and ANOVA analysis, general satisfaction states of the patients significantly differs $(p=0.039)$ with regard to the rooms where the patients have stayed. However, the general satisfaction state has not indicated a significant difference regarding to the other demographic variable types. Satisfaction rate of the patients who have stayed in the single suit room is higher than the satisfaction rates of the patients who have stayed in single private room, single room and double room (Table 3). According to the Table 2, hypothesis numbered H9 is accepted. Hypotheses numbered H1, H2, H3, H4, H5, H6, H7 and $\mathrm{H} 8$ were rejected. Referring to this, the satisfaction does not indicate significant difference with gender, marital status, age, educational status, occupation, monthly income level, social security, residence and hospitalization frequency.

Table 3: Significance Related to the Rooms Where the Patients Stayed and the Satisfaction Scores

\begin{tabular}{|c|c|c|c|c|c|c|c|}
\hline Room condition & $\mathbf{N}$ & Mean & SS & (I) room condition & $(\mathrm{J})$ room condition & Mean difference (I-J) & Sig. \\
\hline Double room & 84 & 2.95 & 0.260 & \multirow{3}{*}{ Single suit room } & Double room & 0.288 & 0.004 \\
\hline Single room & 110 & 2.97 & 0.268 & & Single room & 0.270 & 0.007 \\
\hline Single private room & 26 & 3.00 & 0.303 & & Single private room & 0.241 & 0.031 \\
\hline Single suit room & 10 & 3.24 & 0.708 & \multicolumn{4}{|c|}{ *. The mean difference is significant at the 0.05 level. } \\
\hline Total & 230 & 2.98 & 0.303 & & & & \\
\hline
\end{tabular}

Besides, when the comparison between the demographic variables and the sub scales of satisfaction examined, significant differences have been found in some dimensions. 
Satisfaction of polyclinic services indicates significant difference $(p=0.047)$ with regard to the gender. Men are more satisfied with the polyclinic services than the women.

Satisfaction of employee services $(\mathrm{p}=0.046)$ and physical condition $(\mathrm{p}=0.029)$ indicate significant difference with regard to the marital status. Married people are more satisfied with the employee services and the physical conditions than the single ones.

Satisfaction of other healthcare services and bureaucratic procedures $(p=0.000)$, cafeteria services $(p=0.033)$ and recommending the hospital $(p=0.029)$ indicate significant difference with regard to the ages of the participants. Significant differences in terms of other healthcare services and bureaucratic procedures have been found between the other age groups and the group of ages 31-45. There is significant difference in terms of the satisfaction of cafeteria services between the age group 46-59 and the age group of 61 and over.

Satisfaction of other healthcare services and bureaucratic procedures $(p=0.000)$ significantly differs with regard to the educational status of the participants. Higher the education level, lower the satisfaction rate of other healthcare services and bureaucratic procedures.

Satisfaction of clinical services $(\mathrm{p}=0.000)$ and other healthcare services and bureaucratic procedures $(\mathrm{p}=0.029)$ indicate significant difference with regard to the monthly income level of the participants. People having 1207-1609 \$ monthly income are less satisfied than the people having lower monthly income. Satisfaction of other healthcare services and bureaucratic procedures increases depending on the income raise.

Satisfaction of physical condition $(p=0.03)$ and recommending the hospital $(p=0.04)$ indicate significant difference with regard to the social security types. People having a health insurance from an organization or institution less likely to recommend the hospital than the people having insurance from social security institution (SGK in Turkish) or holding green card (health card for uninsured people in Turkey). Participants who pay to the hospital within their own opportunities related to their social security policies are less satisfied with the physical conditions than the participants having insurance from SGK and the ones holding green card.

Satisfaction of polyclinic services $(p=0.015)$, other healthcare services and bureaucratic procedures $(p=0.044)$ and physical condition $(p=0.042)$ indicate significant difference with regard to the hospitalization frequency. There is significant difference between the people who were hospitalized for three times or more and the ones who were hospitalized once or twice. Patients who were hospitalized for three times or more are more satisfied with the physical conditions than the others.

Satisfaction of polyclinic services $(p=0.001)$ indicates significant difference with regard to the rooms where the patients have stayed. Patients who have stayed in the single suit room are more satisfied than the ones who have stayed in the single private room, single room and double room.

\subsection{Relation Levels Between the Demographic Variables and the Satisfaction Scores}

Relation between demographical variables scores and dimensions of satisfaction takes place in Table 4. 
Table 4: Relation Levels Between the Demographic Variables and the Satisfaction Scores

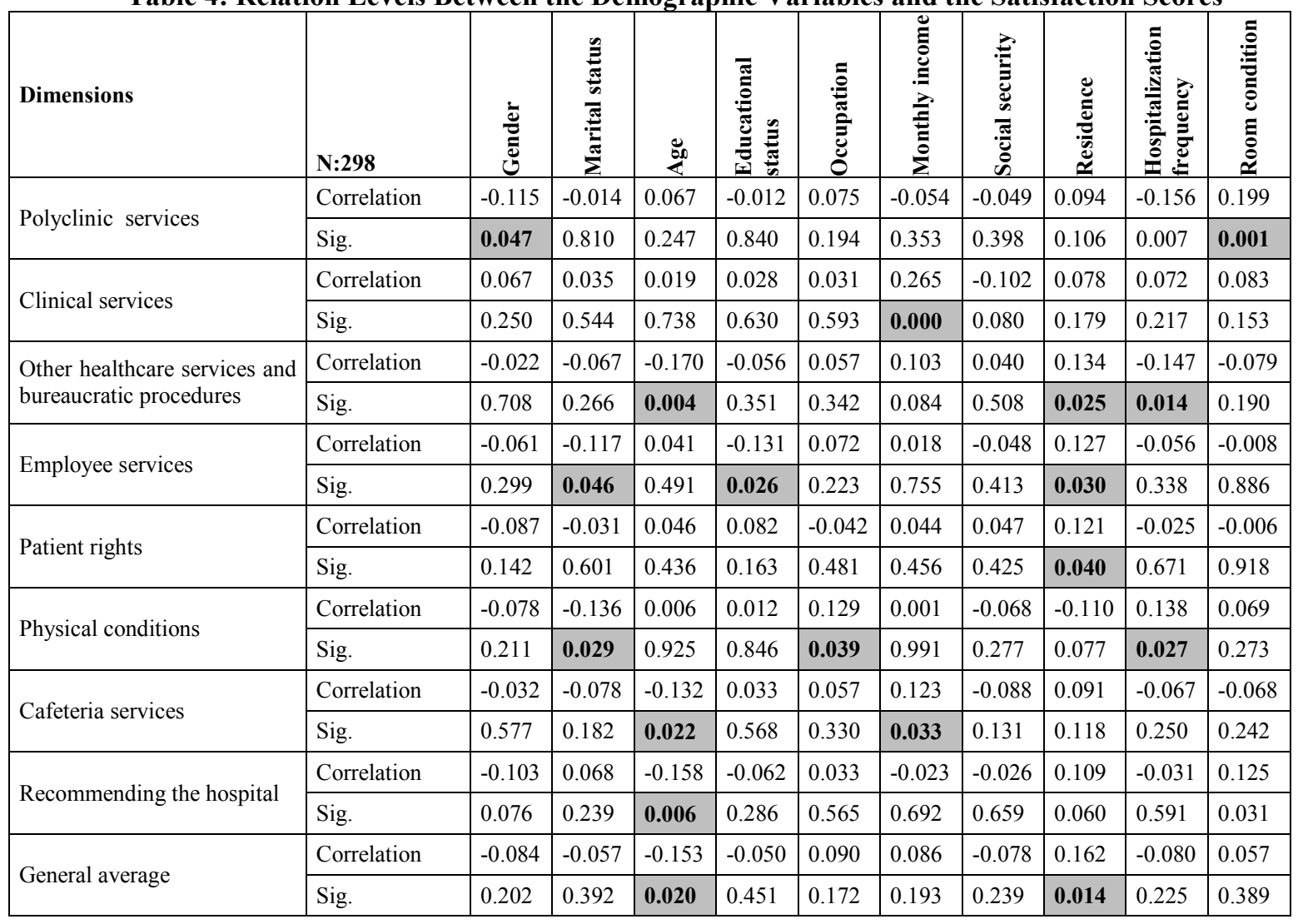

According to the Table 4, negative and low level significant relation $(\mathrm{p}=0.047)$ has been found between the variable of gender and polyclinic services. Significant relation between the variable of gender and the other dimensions of satisfaction has not been found.

Negative and low level significant relation $(p=0.046)$ between the variable of marital status and employee services, and negative and low level significant relation $(p=0.029)$ between the variable of marital status and the physical condition have been found. Significant relation between the variable of marital status and the other dimensions of satisfaction has not been found.

Negative and low level significant relation $(\mathrm{p}=0.04)$ between the variable of age and other healthcare services and bureaucratic procedures, negative and low level significant relation $(\mathrm{p}=0.022)$ between the variable of age and cafeteria services, and negative and low level significant relation $(p=0.006)$ between the variable of age and recommending the hospital have been found. Significant relation between the variable of age and the other dimensions of the satisfaction has not been found.

Negative and low level significant relation $(p=0.026)$ between the variable of education status and employee services has been found. Significant relation between the variable of educational status and the other dimensions of the satisfaction has not been found.

Low level significant relation $(p=0.039)$ between the variable of occupation and physical condition has been found. Significant relation between the variable of occupation and the other dimensions of the satisfaction has not been found.

Low level significant relation $(\mathrm{p}=0.000)$ between the variable of monthly income and clinical services, and low level significant relation $(\mathrm{p}=0.033)$ between the variable of monthly 
income and cafeteria services have been found. Significant relation between the variable of monthly income and the other dimensions of the satisfaction has not been found.

Significant relation between the variable of social security and the dimensions of the satisfaction could not be found.

Negative and low level significant relation $(p=0.014)$ between the variable of hospitalization frequency and other healthcare services and bureaucratic procedures has been found.

Low level significant relation $(\mathrm{p}=0.027)$ between the variable of hospitalization frequency and physical condition has been found.

Low level significant relation $(p=0.001)$ between the variable of room condition and polyclinic services has been found.

\subsection{Relations Between the Variables of "Patient Satisfaction Level" and "Recommending the Hospital"}

Considering the correlation between "Satisfaction Level" of the inpatients and "Recommending the Hospital" $\left(\mathrm{r}=0.401^{* *}\right), \quad(\mathrm{p}: 0.000)$; it is seen that there is a positive midlevel significant relation between them.

Considering the regression between "Satisfaction Level" of the inpatients and "Recommending the Hospital" examined, it is understood that the $15.7 \%$ of the change of "Recommending the Hospital", a dependent variable, depends on the "Patient Satisfaction" which is an independent variable. When the results of ANOVA analyses were examined, it is seen that this relation is significant within $F(1.228)=42.386 ;(0.000),(p<0.01)$ significance level. Our hypothesis numbered H10: There is a significant relation between "Satisfaction Level" of the patients and "Recommending the Hospital" to familiars, has been accepted.

\subsection{Discussion}

In literature, there are different results from the researches on patient satisfaction. However, socio-demographical features which are common in all the studies directly affect the patient satisfaction state (Hekkert, Cihangir, Kleefstra, \& Berg, 2009; Bogale, Kassa, \& Ali, 2015; Quintana, et al., 2006; Ercan, Id1z, \& Kan, 2004) as we have found in our study too.

Majority of the low level significance relations between the variables of age, educational status, monthly income level and dimensions of satisfaction, resulted from the studies performed by Ercan and colleagues (2004), has ensued in our studies similarly. Additionally, significant differences found between the dimensions of satisfaction and the variables are the results of our study, as well.

Hekkert and colleagues (2009) state that there is a very low level relation between gender, mother tongue, type of hospital, size of hospital and population density while they prove that there is an important relation between health status, educational status and satisfaction. Low level significant relation between gender and the satisfaction of polyclinic services has been found in our study, as well.

In their studies Quantina and colleagues (2006) found significant relations between gender and comfort, visits and sincerity, education level and satisfaction of cleanliness and comfort, marital status and patient information and patient care, sincerity and satisfaction of cleanliness, duration of hospital stay and visits and cleanliness while they state that the age 
affects the satisfaction in all dimensions so as the age affects three dimensions of satisfaction in our study.

Çelikalp et al. (2011) stated that there is not a significant relation between age, marital status, educational status, occupation, income level, social security, residence and satisfaction, in their studies. It is thought that low level significant relation occurred due to the factors affecting satisfaction in our study, because the socio-demographical features of the participant patients such as age, gender, occupation and income level are similar. In addition to this, it is seen that as the hospitalization frequency gets higher, the rate of satisfaction increases even at a low level.

\section{Conclusion and Suggestions}

Regardless of dealing with producing or service, business nowadays are focusing more on the customer. The business, satisfying its customer, can turn its customer into a loyal one. Also health business concentrates on customer oriented operations and studies aimed at measuring customer satisfaction, as all the business bodies. In recent years, studies on satisfaction shows an increase at the level of satisfaction rate of the healthcare services when compared to the past. In the life satisfaction researches performed by TUIK it is seen that the satisfaction of healthcare services today is more than $70 \%$ while it was about $50 \%$ in 2004 . This data involves the satisfaction of all healthcare services and is a general assessment.

Variables of patient satisfaction are examined under three titles, in general. These variables may be defined as the ones related to the patient (age, gender, education status, income level, marital status, ethnicity, residence, occupation, social security, diagnosis of disease, treatment experience), the ones related to service providers (employee behavior, information about disease, interaction between the patient and the employee, etc.) and the ones related to the institution (physical and environmental conditions, bureaucracy, etc.).

In this study, it has been found that the hospital services related general satisfaction rate of patients according to the SMSS is $74.9 \%$ and it is evaluated to be at a good level. This result is better than $72.3 \%$ which is the patient satisfaction rate in 2015 , in Turkey. It is seen that, the satisfaction of patient information, employee services, polyclinic services, clinical services, recommending the hospital, and other healthcare services and bureaucratic procedures are at a high level but the satisfaction rate of physical condition of the hospital, and cafeteria services are between $66-68 \%$ and they need to be improved, when the dimensions of patient satisfaction are examined. These results show that the perception of inpatients in cardiovascular surgery is fine in general, however, this perception can be developed in some dimensions. These results are feedback for public relations department and can be used as tool to identify the programme and policy in order to increase the customer satisfaction. Rate of recommending the hospital to others means the public opinion and the reputation of the hospital, as well. Rate of recommending the hospital is about $73 \%$ in this study and it shows that the public opinion and the reputation of the Cardiovascular Surgery Service is at a good level.

In this research, gender, marital status, age, educational status, occupation, monthly income level, social security, residence, hospitalization frequency, room condition and recommending the hospital to others are evaluated as the factors that affect the patient satisfaction. Patient satisfaction was investigated in a single piece as a whole with the general scale score, and as a parts of a whole with eight sub scales in the study. Gender has a significant relation with satisfaction in one dimension while marital status has in two dimensions, age has in four dimensions, education status has in one dimension, occupation has in one dimension, monthly income has in two dimensions, hospitalization frequency has 
in two dimensions, and room condition has in one dimension. In general satisfaction situation, it is seen that there is positive low level significant relation between the variable of age and residence. Besides, general satisfaction does not have significant relation with the other variables except the room where the patients have stayed.

It is seen that there is positive midlevel significant relation between the satisfaction rate of inpatients" and recommending the hospital. Likewise, it is seen that the $15.7 \%$ of the change of "Recommending the Hospital", a dependent variable, depends on the "Patient Satisfaction" which is an independent variable and this relation is significant. In this case, our eight hypotheses were rejected, two of them were accepted. This relation between the patients satisfaction and recommending the hospital is also important in terms of the reputation of the hospital. The satisfaction rate of the hospital investigated in this study is higher than the average of Turkey and it shows that the corporate reputation of this hospital is high. However, it is considered that the hospital management should take corrective actions for the dimensions of low satisfaction rates, in parallel with the planning of public relations department.

Giving educations to the healthcare professionals in terms of converting the relation between healthcare professionals and the patients into a cooperation of healthcare professionals and the patients will be helpful. These educations will be beneficial to contain the subjects and the notions of patient psychology, effective communication, body language and empathy. This should not be forgotten that the matter in the medical advice that stands out is sometimes the effective communication, especially, and the healthcare professional who acts warmly and in a sincere manner is always recommended.

Considering that patient satisfaction is highly related with employee satisfaction, it will be very useful to concentrate on the public relation activities in house in order to raise the moral and increase the motivation of the employees in the hospital.

As a result, it is seen that service quality and public relations affect the "customer (patient) satisfaction" and customer satisfaction affects the "recommending".

\section{References}

Bogale, L. A., Kassa, H. B., \& Ali, J. H. (2015). Patients' perception and satisfaction on quality of laboratory malaria diagnotic service in Ambara Regional, North West Ethiopia. Malaria Journal, 14(241), 2-7, DOI: 10.1186/s12936-015-0756-6

Celikalp, U., Temel, M., Varol Saracoglu, G., \& Demir, M. (2011). Bir kamu hastanesinde yatan hastaların hizmet memnuniyeti. Journal of Firat Health Care, 6(17), 1-14.

Cinaroglu, S., \& Sahin, B. (2012). Kurumsal itibarın hastanelerin performansı ile ilişkisi. Journal of H.U. Economics and Administrative Sciences Faculty, 30(2), 27-56.

Deitrick, L., Bokovoy, J., Stern, G., \& Panik, A, . (2006). Dance of the call bells. Using entografy to evaluate patient satisfaction with quality of care. Journal Nursing Care Quality, 21(4), 316-324.

Draper, M., Cohen, P., \& Buchan, H. (2001). Seeking consumer views: what use are results of hospital patient satisfaction surveys? International Journal for Quality in Health Care, 13(6), 463-468, DOI: 10.1093/intqhe/13.6.463 463-468.

Ercan, I., Idız, B., \& Kan, I. (2004). Hastaların sosyo-ekonomik durumlarına gore saglik hizmetlerinden memnuniyetlerinin incelenmesi. Journal of Inonu University Medical Faculty, 11(3), 161-167.

Gecikli, F. (2013). Halkla iliskiler ve iletisim. Istanbul: Beta Basim Co. 
Gordon, T., \& Edwards, W. (1997). Doktor-hasta isbirligi. Istanbul: Sistem Publishing.

Hatem, G. (2015). Service quality and patients satisfaction in Tunisian public hospitals. Europan Researcher, 94(5), 365-373. DOI: 10.13187/er.2015.94.365.

Hekkert, K. D., Cihangir, S., Kleefstra, S. M., \& Berg, B. V. (2009). Patient satisfaction revised: A multilevel approach. Social Science \& Medicine, 69(1), 68-75, DOI:10.1016/j.socscimed.2009.04.016

Jenginson, C., Coulter, A., Bruster, S., Richards, N., \& Chandola, T. (2002). Patients' experiences and satisfaction with health care:results of a questionnaire study of specific aspects of care. Quality and Safety in Health Care, 11, 335-339, DOI:10.1136/qhc.11.4.335

Kavuncubasi, S. (2000). Hastane ve saglik kurumlari yonetmeligi. Ankara: Siyasal Publishing.

Kotler, P. (2005). A'dan Z'ye pazarlama. Istanbul: MediaCat Publishing.

Meldrum, H., \& Hardly, L. (2001). Provider-patient partnerships. Boston: ButterworthHeinemann.

Ozer, A., \& Cakil, E. (2007). Saglik hizmetlerinde hasta memnuniyetini etkileyen faktörler. Medical Research Journal, 5(3), 140-143.

Quintana, J. M., Gonzales, N., Bilbao, A., Aizpuru, F., Escobar, A., Esteban, C., et al. (2006). Predictors of patient satisfaction with hospital health care. BMC Health Service Research, 6(102), 1-9, DOI: 10.1186/1472-6963-6-102.

Rahman, M. (2015, Oct.). Patient satisfaction constructs. International Journal of Health Care Quality Assurance, 28(8), 841-854, DOI:10.11087ijhcqa-05-2015-0056.

Rozenblum, R., Gianola, A., \& Lonescu, R. (2015, March-April). Clinicians' perspectives on patient satisfaction in adult congenital heart disease clinics. A dimension of health care quality whose time has come. Congenital Heart Disease, 10(2), 128-136. DOI:10.111/chd.12190.

TUIK. (2015). Genel olarak kamu hizmetlerinden memnuniyet. Retrieved from http://www.tuik.gov.tr/PreIstatistikTablo.do?istab_id=1598

Uz, M. (1997). Hastanelerde kalite yonetimi. In O. Hayran, \& H. Sur (Eds.), Hastane Yoneticiligi (pp. 115-131). Istanbul: Nobel Medical Books. 